Arq. Bras. Med. Vet. Zootec., v.70, n.5, p.1505-1513, 2018

\title{
Electroretinography in eight species of neotropical deer
}

\author{
[Eletrorretinografia em oito espécies de cervídeos neotropicais] \\ R.M. Crivelaro ${ }^{1}$, R. Thiesen ${ }^{2}$, M. Aldrovani ${ }^{1}$, T.B. Lima $^{1}$, K.P. Ortêncio ${ }^{1}$, \\ I.R.M. Padua ${ }^{1}$, J.M.B. Duarte ${ }^{2}$, J.L. Laus ${ }^{1}$ \\ ${ }^{1}$ Universidade Estadual Paulista - Jaboticabal, SP \\ ${ }^{2}$ Universidade Federal de Pampa - Uruguaiana, RS
}

\begin{abstract}
The aim of this study was to establish normal baseline ERG values of 23 anesthetized deer belonging to 8 neotropical species (Mazama americana, Mazama nemorivaga, Mazama gouazoubira, Mazama nana, Mazama bororo, Ozotocerus bezoarticus, Odocoileus virginianus and Blastocerus dichotomus). Only right eyes were studied. Chemical restraint was performed using xylazine associated with ketamine, IM, for M. americana, M. gouazoubira, M. nemorivaga, M. nana, M. bororo, O. bezoarticus and $O$. virginianus. A combination of tiletamine/zolazepam diluted in xylazine $2 \%$ was used for B. dichotomus individuals. After 20min of dark adaptation, electroretinograms were obtained using a handheld electroretinography (ERG) machine using the QuickRetCheck Protocol at three different light intensities: $0.01 \mathrm{~cd} . \mathrm{s} / \mathrm{m}^{2}, 3 \mathrm{~cd} . \mathrm{s} / \mathrm{m}^{2}$, and $10 \mathrm{~cd} . \mathrm{s} / \mathrm{m}^{2}$. After light adaptation, photopic phase was recorded. Awave amplitude recorded during pattern mixed rod/cone response in $M$. americana was significantly lower when compared to $B$. dichotomus. No other differences were observed between the species studied. ERG in Neotropical deer is applicable using a portable ERG system and did not show differences among species in relation to the retinal response at different light intensities. Therefore, the lifestyle of the species is more dictated by the selection pressure of the environment than by physiological factors.
\end{abstract}

Keywords: cervidae, habitat, retina, wild animal, ERG

\section{RESUMO}

Objetivou-se estabelecer valores de referência para eletrorretinografia (ERG) de 23 cervídeos anestesiados, de oito espécies neotropicais (Mazama americana, Mazama nemorivaga, Mazama gouazoubira, Mazama nana, Mazama bororo, Ozotocerus bezoarticus, Odocoileus virginianus e Blastocerus dichotomus). Somente os olhos direitos foram estudados. A contenção química foi realizada com cetamina/xilazina, IM, nas seguintes espécies: M. americana, M. gouazoubira, M. nemorivaga, M. nana, M. bororo, O. bezoarticus e O. virginianus. Para o B. dichotomus, foi utilizada a associação de tiletamina/zolazepam e xilazina. Após 20 minutos de adaptação ao escuro, os eletrorretinogramas foram obtidos com aparelho portátil de ERG, utilizando-se o protocolo "QuickRet Check", em três intensidades de luz: $0.01 \mathrm{~cd} . \mathrm{s} / \mathrm{m}^{2}, 3 \mathrm{~cd} . \mathrm{s} / \mathrm{m}^{2}$ e $10 \mathrm{~cd} . \mathrm{s} / \mathrm{m}^{2}$. Após adaptação à luz, realizou-se a fase fotóptica. Os valores para amplitude da onda A durante a resposta padrão mista de cones/bastonetes em M. americana foram significativamente menores quando comparados aos do B. dichotomus. Não foram observadas outras diferenças entre as espécies. A realização de ERG em cervídeos neotropicais é aplicável utilizando-se aparelho portátil e não demonstrou diferenças quanto à resposta retiniana a diferentes intensidades de luz. Dessa forma, o estilo de vida das espécies é ditado mais pela pressão de seleção do ambiente do que por fatores fisiológicos.

Palavras-chave: cervídeos, habitat, retina, animais selvagens, ERG

Recebido em 5 de julho de 2017

Aceito em 29 de agosto de 2017

E-mail: roberta.crivelaro@gmail.com 


\section{INTRODUCTION}

Cervids form a subclass of ruminant artiodactyles and play important roles in ecosystem health and sustainability (Duarte and Gonzalez, 2010). They inhabit Eurasia, the Americas, and potentially northernmost Africa (Duarte and Gonzalez, 2010). In Brazil, many species of neotropical deer have been exhibiting sharp population decline, among other serious problems, due to habitat loss, disease, and hunting (Tomas et al., 1997). Knowledge of the morpho-functionality of deer body structures is a critical part of their conservation research programs.

There is little data on the ocular morphophysiology of the different deer species (Jacobs et al., 1994; Martins et al., 2007). Studies in this scope are important for evolutionary and environmental reasons, since the vision of each animal seems to adapt to its lifestyle (Osorio and Vorobvev, 2008; Nilsson, 2009). Furthermore, several quali-quantitative ophthalmic parameters usually assessed for diagnosing and treating the ocular diseases are species-specific, and the extrapolation between species is not always appropriate (Balthazar da Silveira et al., 2017).

Many different deer species occupy distinct habitats and possess variable activity periods (crepuscular, diurnal, and nocturnal), and the eyes are expected to be morphophysiologically adapted to the physical characteristics, notably the light intensity, of the environment (Schimitz and Montani, 2010). For example, a previous study showed a pigment ring lodged deep into the cornea of diurnal deer, but not in crepuscular or nocturnal deer, which could act as antireflective device that favors vision in high luminosity conditions (Duke-Elder, 1958). In nocturnal deer, the tapetal zone of the retina (called tapetum fibrosum) seems to act as mirror, which reflects the light absorbed into the photoreceptor layer and favors the vision in low luminosity conditions (Duke-Elder, 1958). Although differences in sensitivity of photoreceptor cells to light stimulus seem to partially dictate the mammalian lifestyle, (McNeil et al., 2008) there is as yet no data on the retinal function of different deer species.

The morphological and molecular features of the photoreceptor cells from mammals represent a complex pattern of evolutionary genetic events, leading to a number of different light-sensitive systems (Mcllwain, 1996; Nilsson, 2009). The functionality of these systems can be evaluated by different electroretinography (ERG) techniques (Narfstrom et al., 2002a), such as flash ERG, which allows the evaluation of the external layers of the retina, through a light stimulus with controlled intensity, frequency, and color (Honsho et al., 2004). The main components of flash ERG are the a-wave (negative deflection) that originates in the outer layers, as a result of the activity of cones and rods, and the b-wave (positive deflection) that originates from the depolarization of Müller and bipolar cells (Oriá et al., 2004).

In this work, the retinal functionality of 23 deer belonging to 8 Neotropical species with different lifestyles were studied. The examination environment and equipment were identical for all. The aims of this study were to establish normal baseline ERG values and to evaluate any significant differences in ERG parameters between these 8 Neotropical deer species. Also, a comparison between diurnal and nocturnal/crepuscular species was performed.

\section{MATERIALS AND METHODS}

The research was carried out with the consent of the Brazilian Institute for the Environment and Renewable Natural Resources (IBAMA-BR) (protocol number 3524.3804/2010/SP), and after authorization by the committee on ethics in the use of animals of our institution (protocol number 013280/12).

The right eyes of the 23 deer (male or female) from 8 species were studied. Mazama nemorivaga ( $\mathrm{n}=3$, two male), Blastocerus dichotomus ( $\mathrm{n}=3$, one male) and Ozotocerus bezoarticus $(\mathrm{n}=1$, male) have preferably diurnal habits, while Mazama americana ( $\mathrm{n}=6$, three males), Mazama nana ( $\mathrm{n}=2$, one male) and Mazama bororo $(\mathrm{n}=1$, one male) have nocturnal life habits. Mazama gouazoubira $(\mathrm{n}=6$, three males) and Odoicoleus virgininanus $(\mathrm{n}=1$, male) are considered crepuscular animals (Oliveira et al., 2016). All animals of this study belong to the Center for Research and Conservation of Cervidae (NUPECCE) from the School of Agricultural and Veterinarian Sciences of Jaboticabal (São Paulo, Brazil). All were free of systemic diseases. All individual weights were 
obtained when animals entered a containment cage positioned over a scale, except for $B$. dichotomus individuals, which had their weight estimated.

Chemical restraint was performed using $1 \mathrm{mg} . \mathrm{kg}$ 1 of xylazine hydrochloride 2\% (Virbaxyl, Virbac, São Paulo, Brazil) associated with $7 \mathrm{mg} . \mathrm{kg}-1$ of ketamine hydrochloride (Vetaset, Fort Dodge, Campinas, Brazil), intramuscularly (IM), in a single application, for all $M$. americana, $M$. gouazoubira, $M$. nemorivaga, $M$. nana, $M$. bororo, $O$. bezoarticus, and $O$. virginianus. The drugs were injected directly by syringe while the animals were inside the containment cage. For B. dichotomus, it was used as a $3 \mathrm{mg} . \mathrm{kg}-1$ of tiletamine/zolazepam (Zoletil 50; Virbac; São Paulo, Brazil) diluted with $3 \mathrm{~mL}$ of $2 \%$ xylazine $(0.75 \mathrm{mg} . \mathrm{kg}-1)$. In these animals, drugs were delivered by darts that were fired with a $\mathrm{CO}_{2}$ gun (JM Standard-13mm; Austins; USA). Anesthesia monitoring was performed by assessing heart rate, respiratory rate and rectal temperature at ten-minute intervals.

Prior to the exam, one drop of $1 \%$ tropicamide (Mydriacyl; Alcon; Paulo; Brazil) was instilled in both eyes to produce pupillary dilation and an ophthalmic examination was performed, including applanation tonometry and Schirmer tear test. The deer were then submitted to a 20 minute dark adaptation period, using a black blind fold placed over the eyes.
For the ERG exam, a handheld device (Handheld Multispecies - ERG; Kansas; USA) was used. The ground electrode was positioned over the crest of the occipital bone between the two ears, and the reference electrode over the zygomatic arch, approximately $5 \mathrm{~cm}$ lateral to the lateral canthus. The negative electrode (corneal electrode) was positioned over the cornea surface. A 2\% methylcellulose lube (Infarmed, Lisboa, Portugal) was used at the electrodecornea interface. Electroretinography was performed in two phases. In the scotopic phase, the QuickRetCheck Protocol was employed at three different light intensities: $0.01 \mathrm{~cd} . \mathrm{s} / \mathrm{m}^{2}$, 3cd.s $/ \mathrm{m}^{2}$, and 10cd.s $/ \mathrm{m}^{2}$ (Labelle et al., 2010). At the end of this phase, deer were submitted to a 10-minute period of light adaptation with continuous illumination of $30 \mathrm{~cd} . \mathrm{s} / \mathrm{m}^{2}$. Afterwards, the photopic phase was performed (Table 1).

A D'Agostino-Pearson test was used to test for normality. When possible (due to sample size), data collected for different species were statistically compared using One-way ANOVA. A Tukey post-test was used when necessary with $\mathrm{P}<0.01$. This confidence interval was adopted due to reduced sample size. To compare diurnal and nocturnal/crespuscular species, an unpaired t-tesut with $\mathrm{P}<0.05$ was used. Data are expressed as mean \pm standard deviation (SD).

Table 1. Protocols used for ERG in eight deer species of the Brazilian fauna

\begin{tabular}{|c|c|c|c|c|}
\hline Phase & Function & Intensity "Flash" & $\begin{array}{l}\text { Frequency } \\
\text { "Flash" }\end{array}$ & Type of light \\
\hline $\begin{array}{l}\text { Phase } 1 \\
\text { scotopic }\end{array}$ & Rods & $-2.5 \log \left(0.01 \mathrm{~cd} . \mathrm{m} / \mathrm{s}^{2}\right)$ & $5 . \mathrm{Hz}$ & White \\
\hline $\begin{array}{l}\text { Phase } 2 \\
\text { scotopic }\end{array}$ & Cone and rods & $\begin{array}{c}0 \log \\
\left(3 \mathrm{~cd} \cdot \mathrm{m} / \mathrm{s}^{2}\right)\end{array}$ & $5.1 \mathrm{~Hz}$ & White \\
\hline $\begin{array}{l}\text { Phase } 3 \\
\text { scotopic }\end{array}$ & Cone and rods & $\begin{array}{c}0,5 \mathrm{log} \\
\left(10 \mathrm{~cd} \cdot \mathrm{m} / \mathrm{s}^{2}\right)\end{array}$ & $5.1 \mathrm{~Hz}$ & White \\
\hline \multicolumn{5}{|c|}{ Adaptation to light } \\
\hline Photopic & Cone & $\begin{array}{c}0 \log \\
\left(3 \mathrm{~cd} \cdot \mathrm{m} / \mathrm{s}^{2}\right)\end{array}$ & $5.1 \mathrm{~Hz}$ & White \\
\hline Photopic & Cone & $\begin{array}{c}0 \log \\
\left(3 \mathrm{~cd} \cdot \mathrm{m} / \mathrm{s}^{2}\right)\end{array}$ & $30.0 \mathrm{~Hz}$ & White \\
\hline
\end{tabular}

\section{RESULTS}

A representative ERG, recorded from $M$. americana, is presented in Figure 1 and 2, showing the scotopic and photopic phases, respectively. At the time of ERG recording, all deer were considered normal according to ophthalmic examination, were normothermic, had normal arterial oxygenation, estimated by pulse oximetry (99-100\%), and were considered to have normal ventilatory effort. 


\section{Crivelaro et al.}

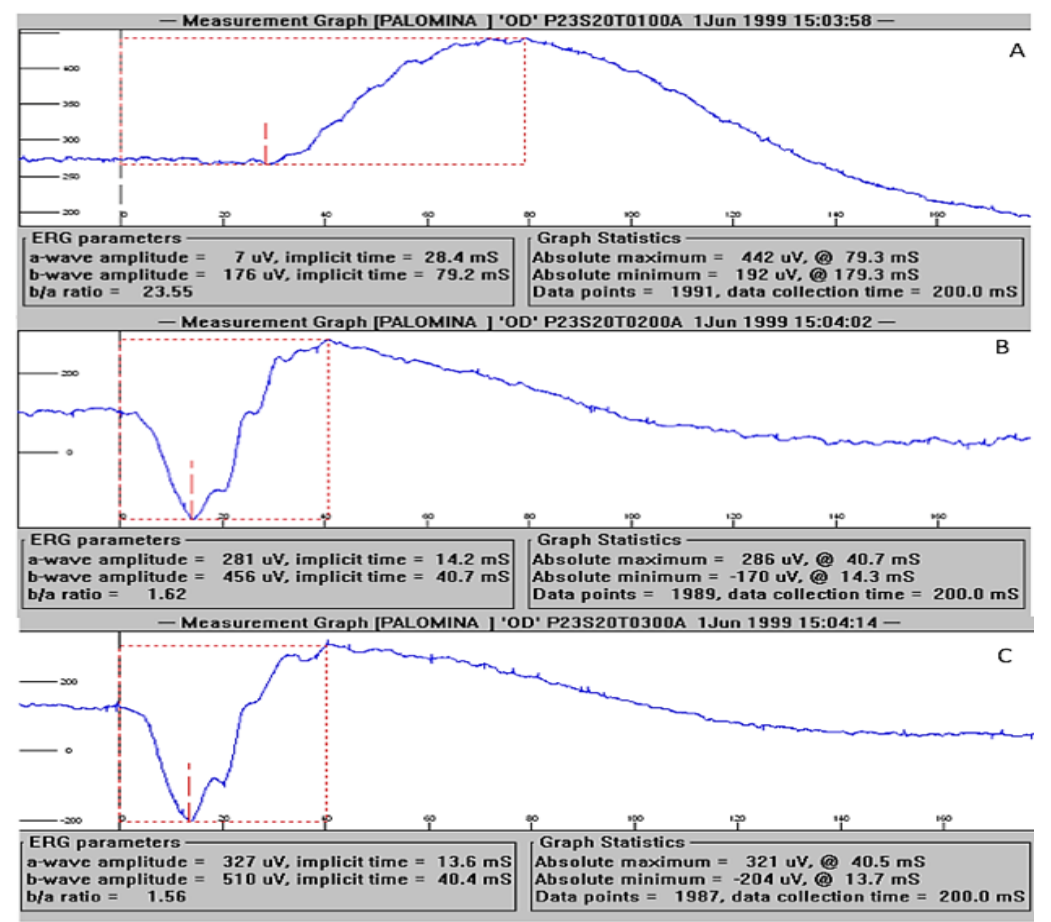

Figure 1. Representative curves using the QuickRetCheck protocol in a M. americana deer. (A) response of rods to $0.01 \mathrm{~cd} . \mathrm{s} / \mathrm{m}^{2}$ luminous stimulus. (B) response to $3 \mathrm{~cd} . \mathrm{s} / \mathrm{m}^{2}$ luminous stimulus (C) response to $10 \mathrm{~cd} . \mathrm{s} / \mathrm{m}^{2}$ luminous stimulus.

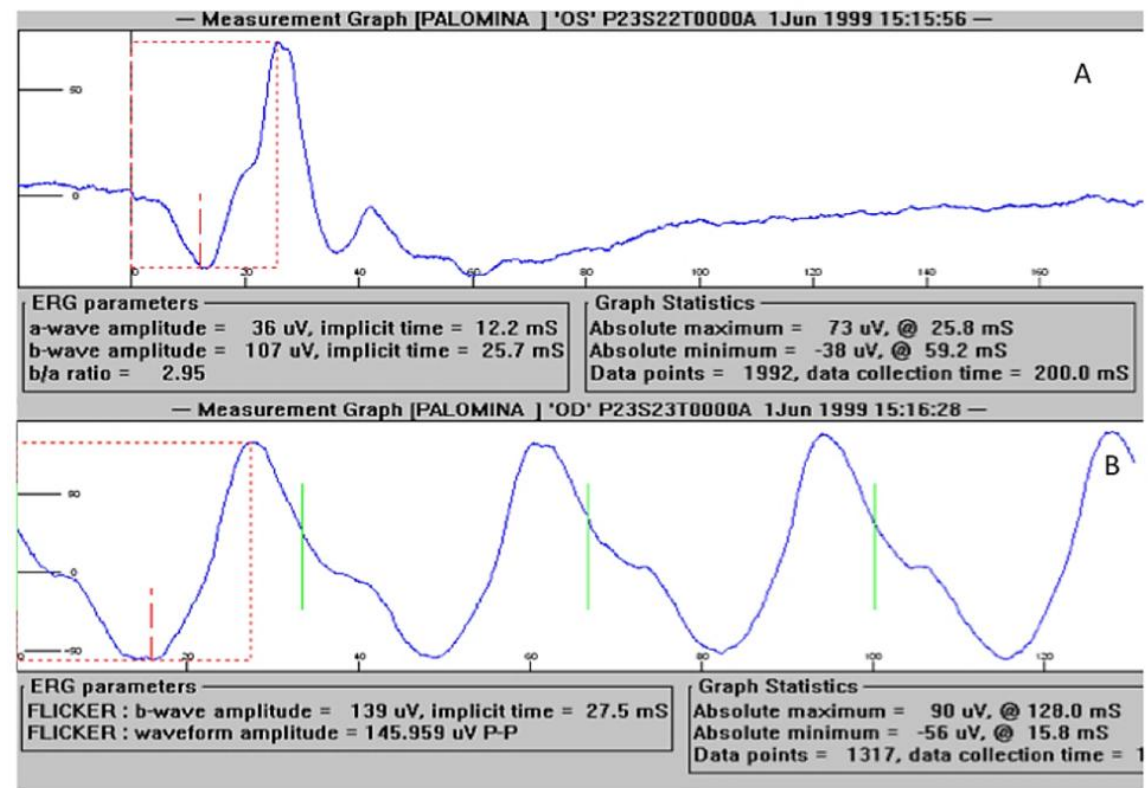

Figure 2. Representative curves using the protocol for cones in a M. americana deer. (A) Representation of the photopic phase waves, 10min of light adaptation (B). Representation of the flicker waves - strobe light.

Electroretinography values are shown in Table 2. A-wave amplitudes were significantly lower in $M$. americana $(174 \mu \mathrm{V})$ when compared to $B$. dichotomus $(45 \mu \mathrm{V})(\mathrm{P}<0.001)$, at light intensity of $3 \mathrm{~cd} . \mathrm{s} / \mathrm{m}^{2}$ of scotopic phase $(\mathrm{P}<0.01)$. 
Table 2. Flash ERG parameters in eight species of Neotropical deer, at different light intensities (data expressed as mean $\pm S D$, or single value when $n=1$ )

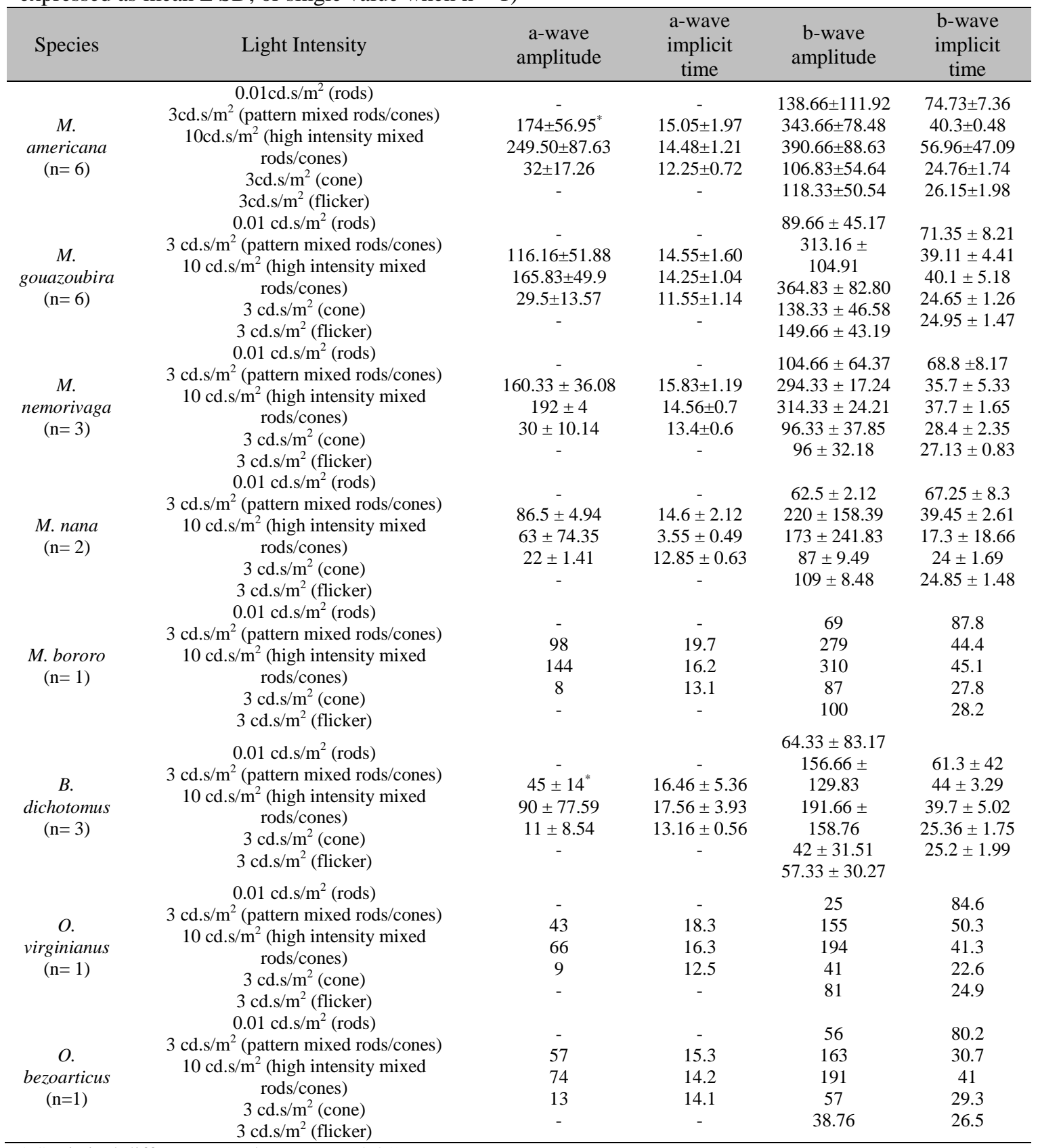

* Statistical differences (Tukey test, $\mathrm{P}<0.01$ ).

Crepuscular/nocturnal species $(n=14)$ showed higher b-wave amplitude values of mixed rods/cones response when compared to diurnal species $(\mathrm{n}=9)$ at $3 \mathrm{~cd} . \mathrm{s} / \mathrm{m}^{2} \quad(312.5 \pm 95.11$ vs $217.3 \pm 106.8 \quad(\mathrm{P}=0.045))$ and at $10 \mathrm{~cd} . \mathrm{s} / \mathrm{m}^{2}$ $(359.8 \pm 91.73$ vs $228.3 \pm 134.1 \quad(\mathrm{P}=0.023))$. Bwave of cone response at $3 \mathrm{~cd} . \mathrm{s} / \mathrm{m}^{2}$ also was higher in crepuscular/nocturnal species, with values being $114.2 \pm 52.4$ compared to $71.78 \pm 35.53(\mathrm{P}=0.031)$ for diurnal species. On flicker, b-wave amplitude was also significantly higher in crepuscular/nocturnal species $(127.8 \pm 47.89)$ when compared to diurnal ones (79.44 \pm 35.03$)(\mathrm{P}=0.011)$. 


\section{DISCUSSION}

This study describes a feasible technique for performing ERG in different species of deer, not only enhancing collective knowledge of vision patterns, but also leading to a better understanding of visual physiology in wild species and its relation to lifestyles, periods of activity, and the environment. The species included in this study have distinct activity periods. As a result, the retina response to different light intensities in different species of Brazilian deer kept in captivity was evaluated. All deer had unilateral ERGs recorded using a monopolar contact lens corneal electrode and a hand-held ERG machine (HMsERG). These factors increased the feasibility of the technique in free-ranging captive and wild species. ERG was previously reported in other exotic species, like koalas (Phascolarctos cinereus), kangaroos (Macropus fuliginosus), and two wild cats (Prionailurus viverrinus and Prionailurus bengalensis) (Labelle et al., 2010; Liddle, 2015; Sussadee et al., 2017), but not in deer. The study also aimed to obtain reference range values for the species, since the number of captive animals in zoos, conservation centers, and commercial properties, is increasing more and more. These animals are not free from traumas. Indeed, it is a common occurrence in captive deer. Most injuries happen in limbs and in the head, which may include ocular traumas such as ulcers, traumatic cataracts, and retina displacement.

There are many factors that may interfere with ERG recordings, making them less precise and reliable. These factors may include a poor contact between the corneal electrode and corneal surface, incorrect placement of ground and reference needles, irrelevant physiologic activity, excessive environmental electric interference, and inadequate or defectives electrodes, filters, and amplifiers (Komaromy et al., 2002; Liddle, 2015). To minimize these, electrodes were changed every 3 animals. Also, the room where the exams were performed had no electrical isolation. Nevertheless, all electronic devices in a 20m-range were turned off, except the pulse oximeter. The table used to place the animals for the exam had a rubber cover, reducing possible electrical interference. The exams were always performed in the morning in an attempt to minimize circadian interference.
Another factor to consider is that the corneal electrode used is made for dogs, which have different corneal curvature and globe size when compared with deer. A study comparing ERG in four dog breeds - Poodle, Labrador Retriever, Thai Ridgeback, and Thai Bangkaew - reported that the breed of dog was an important variable in ERG, possibly based on the variation in skull conformation (Sussadee et al., 2015). There was a significant difference of the average body weights for each species in the present study.

Although ideal conditions for ERG recording were not established in the present study, all waves in all animals demonstrated to be stable and values reliable. The skin in deer is not too thick, so the electrode needles were easily positioned subdermally. In male individuals, the ground electrode was positioned between the antlers, but no interference was noted, leading to the belief that these structures do not interfere with the recordings. The dark adaptation time used in this study was extrapolated from that recommended for dogs (Nardstrom et al., 2002), and that were also used in koalas (Liddle, 2015). Based on the results achieved, the authors believe that this time was enough for deer. However, it is not possible to confirm that; additionally, the black fold used to cover the eyes may not have been dark enough for a complete dark adaptation.

The QuickRetCheck protocol used in this study was developed to be a fast screening test, making it ideal for use in wild animals under field conditions. It has previously been utilized in dogs, kangaroos, koalas, and wild cats (Labelle et al., 2010; Liddle, 2015; Sassadee et al., 2017). Nevertheless, it does not provide information about cone function separately. For that, a photopic ERG recording was performed using a light adapted flash test and a flicker response test using the same conditions described for dogs (Narfstrom et al., 2002b).

Results of two previous studies (Jacobs et al., 1994; VerCauteren, Pipas, 2003) with $O$. virginianus demonstrated that these animals present 3 classes of photopigments, one associated with rods and two associated with cones, with different spectral sensitivity. The ones associated with cones had peaks sensitive to light beams of low to medium wavelength 
$(450-537 \mathrm{~nm})$. The one associated with rods was sensitive to bundles with low wavelength (maximum sensitivity of $497 \mathrm{~nm}$ ). The abundance of cones and rods on their retina allows for good daytime and night vision. During the day, they are able to distinguish colors from blue to yellow, as well as waves of high lengths (red to orange). At night, they define colors primarily from blue to green. Jacobs et al. (1994) demonstrated that deer have lack of rod-free areas in retina, fact that would contribute to better night vision. On other hand, values obtained in the present study for rods and mixed rods/cones response to different light intensities in $O$. virginianus were lower than in the other species, which would represent poor night vision. The contradictory results make, along with the small sample, impossible to affirm if the specie has vision better adapted for night or day. However, it is known that it has crepuscular habits.

At $3 \mathrm{~cd} . \mathrm{s} / \mathrm{m}^{2}$, a-wave amplitude was higher in $M$. americana when compared with $B$. dichotomus, which was the only difference registered in this study. The two species have completely different lifestyles. The former is adapted to areas with highly dense forests and have habits predominantly nocturnes, while the latter species is typical of open fields and swampy grounds, with diurnal and crepuscular habits (Duarte and Gonzalez, 2010). As b-wave amplitude and implicit times did not differ, it would be plausible to admit that the responses to different light stimuli in these species, whose lifestyles are distinct, do not diverge. However, it has to be considered that the small samples in some species may have caused a statistic type II error. For example, b-wave amplitude at $3 \mathrm{~cd} . \mathrm{s} / \mathrm{m}^{2}$ obtained for the two species cited above presented great differences in values. In $M$. americana, values were $119 \%$ higher than in $B$. dichotomus, but no statistical differences were registered. This situation happened in other comparisons, so is important to consider this when interpreting the results.

M. americana and M. nana prefer to be nocturnal in their habits (Oliveira et al., 2016). However, in areas where they cohabit, the first one tends to have a nocturnal activity pattern, while the second one maintains a diurnal pattern (Bitetti et al., 2008). O. virginianus have crepuscular habits (Oliveira et al., 2016), however its activity pattern may change in response to hunting activity or human presence in its habitat (Kilgo et al., 1998). A study with M. bororo showed that they have nocturnal and crepuscular activity periods, possibly related to anti-predatory strategies, reproductive cycles, and resource availability during the year (Vogliotii, 2003). In the same study, $M$. bororo demonstrate preference for smaller and more preserved areas when compared to $M$. gouazoubira, which lives in more anthropized areas. $M$. nemorivaga presents great ecological plasticity, which permits its movement within different landscapes (Duarte et al., 2008). O. bezoarticus is a species that lives in more open areas and has diurnal life habits (Oliveira et al., 2016), however it can show a polymodal pattern of activity, with one diurnal and one nocturnal peak of activity (Rodrigues, 1996).

The results obtained when comparing nocturnal/crepuscular and diurnal species show that the first ones present a more sensitive retina when compared with the last ones, as the responses were higher at same light intensities. The authors believe that this higher sensitivity is an adaptation for the life habits of these species, which are more active when light conditions are poor. One possible explanation for this could be that the nocturnal/crepuscular species may have more retinal cells when compared to species with diurnal habits. More studies to test this hypothesis are necessary.

In veterinary medicine, routine investigations of retina have to be performed under anesthesia in order to facilitate the restraint, positioning, and to minimize the anxiety of the animals. Also, eye movement could potentially induce amplitude variations in ERG (Nair et al., 2011). Several anesthetic protocols have already been documented as to the effects on ERG values evaluated in different species (Narfstrom et al., 2002a; VerCauteren, Pipas, 2003; Jeong et al., 2009; Lin et al., 2009; Nair et al., 2011). The anesthetic protocol used in this case was based on dissociative agents, as these agents provide a quick and reliable chemical immobilization and light anesthesia in several deer species, avoiding accidents with animals and members of the research team (Caulkett, Haigh, 2007). In dogs, ketamine/xylazine association demonstrated higher a-wave implicit times and amplitude when compared to a barbituric and inhalation 
combination (Jeong et al., 2009). The same protocol in rats showed the largest a- and b-wave amplitudes when compared to different inhalation agents (Nair et al., 2011). Also, tiletamine-zolazepam showed higher ERG values when compared with inhalation anesthetics in dogs, becoming a desirable choice to perform ERG in that species (Lin et al., 2009). Therefore, it is unlikely that the protocols used here (i.e. ketamine/xylazine, or tiletaminezolazepam/xylazine) significantly affected the ERG. Given the natural behavior of the species studied, it would be impossible to perform the exams without anesthesia. Therefore, the ERG values provided here may be considered a reference range, when using dissociative agents.

\section{CONCLUSIONS}

ERG in wild animals is not a common practice. Although research protocols and clinical screening have been described, there are few data available. In the present study, however, the methodology applied was considered feasible and operational. Portable devices, such as the HMsERG-ERG, significantly increase the possibility of performing electroretinography in exotic species outside the hospital environment, opening up promising new prospects. In the species studied, no differences were identified in relation to the retinal response at different light intensities, suggesting that these animals have both adaptations for diurnal and nocturnal/crepuscular vision. Therefore, the lifestyle of the deer species is more dictated by the selection pressure of the environment than by physiological factors.

\section{REFERENCES}

BALTHAZAR SILVEIRA, C.P.; LIMA, T.B.; CRIVELARO, R.M. et al. Ophthalmic parameters in adult lowland paca (Cuniculus paca) raised in captivity. Vet. Ophthal., 2017. (Epub ahead of print).

BITETTI, M.S.D.; PAVIOLO, A.; FERRARI, C.A.; ANGELO, C.D.; BLANCO, Y.D. Differential responses to hunting in two sympatric species of Brocket deer (Mazama americana and M. nana). Biotropica, v.40, p.636-645, 2008.
CAULKETT, N.; HAIGH, J.C. Deer (cervids). In: WEST, G.; HEARD, D.; CAULKETT, N. Zoo animal and wildlife immobilization and aneshtesia. Iowa: Blackwell Publishing, 2007. p.607-612.

DUARTE, J.M.B.; GONZÁLEZ, S. Neotropical cervidology: biology and medicine of Latin American deer. Jaboticabal: Funep, 2010. p.160165.

DUARTE, J.M.B.; GONZÁLEZ, S.; MALDONADO, J.E. The surprising evolutionary history of South American deer. Mol. Phylog. Evol., v.49, p.17-22, 2008.

DUKE-ELDER, S. The eye in evolution. In: DUKE-ELDER, S. System ophthalmology. St. Louis: Mosby Company, 1958. 902p.

HONSHO, C.S.; ORIÁ, A.P.; LAZARO JÚNIOR, L.P.V.M. et al. The organization of flash electroretinography unit in Veterinary Medicine. Ciênc. Rural, v.34, p.1097-1104, 2004.

JACOBS, G.H.; DEEGAN, J.F.; NEITZ, J. et al. Electrophysiological measurements of spectral mechanisms in the retinas of two cervids: whitetailed deer (Odoicoileus virginianus) and fallow deer (Dama dama). J. Comp. Phisiol. A, v.174, p.551-557, 1994.

JEONG, M.B.; NARFSTROM, K.; PARK, S.A. et al. Comparison of the effects of three different combinations of general anesthetics on the electroretinogram of dogs. Doc. Ophthal., v.119, p.79-88, 2009.

KILGO, J.C.; LABISKY, R.F.; FRITZEN, D.E. Influences of hunting on the behavior of whitetailed deer: Implications for conservation of the Florida panther. Conserv. Biol., v.12, p.13591364, 1998.

KOMAROMY, A.M.; BROOKS, D.E.; DAWSON, W.W. et al. Technical issues in electrodiagnostic recording. Vet. Ophthal., v.5, p.85-89, 2002.

LABELLE, A.L.; HAMOR, R.E.; NARFSTRÖM, K. et al. Electroretinography in the western gray kangaroo (Macropus fuliginosus). Vet. Ophthal., v.1, p.41-46, 2010.

LIDDLE, V.L. Electroretinography in the normal koala (Phascolarctos cinereus). Vet. Ophthal., v.18, p.74-80, 2015. 
LIN, S.L.; SHIU, W.C.; LIU, P.C. et al. The effects of different anesthetic agents on short electroretinography protocol in dogs. J. Vet. Med. Sci., v.71, p.763-768, 2009.

MARTINS, B.C.; ORIÁ, A.P.; SOUZA, A.L.G. et al. Ophthalmic patterns of captive brown brocket deer (mazama gouazoubira). J. Zoo Wild. Med., v.38, p.526-532, 2007.

MCLLWAIN, J.T. An introduction to the biology of vision. Cambridge: Cambridge University Press, 1996. 222p.

MCNEIL, D.S.; ALTIMUS, C.M.; HATTAR, S. Retina-clock relations dictate nocturnal to diurnal behaviors. Proc. Nat. Acad. Sci. USA., v.105, p.12645-12646, 2008.

NAIR, G.; KIM, M.; NAGAOKA, T. et al. Effects of common anesthetics on eye movement and electroretinogram. Doc. Ophthal., v.122, p.163-176, 2011.

NARFSTROM, K.; EKESTEN, B.; ROSOLEN, S.G. et al. Committee for Harmonized ERG Protocol. Eur. Col. Vet. Ophthal., v.105, p.83-92, 2002a.

NARFSTROM, K.; EKESTEN, B.; ROSOLEN, S.G. et al. Guidelines for clinical electroretinography in the dog. Doc. Ophthal., v.105, p.83-92, 2002b.

NILSSON, D.E. The evolution of eyes and visually guided behavior. Philos. Trans. $B$. v.364, p.2833-2847, 2009.

OLIVEIRA, M.L.; PERES, P.H.F.; VOGLIOTTI, A. et al. Phylogenetic signal in the circadian rhythm of morphologically convergent species of neotropical deer. Mamm. Biol. v.81, p.281-289, 2016.

ORIÁ, A.P.; LÁZARO JÚNIOR ， L.P.; HONSHO, C.S. et al. Considerations about electroretinography in dogs. Ciênc. Rural, v.34, p.323-328, 2004.
OSORIO, D.; VOROBYEV, M. A review of the evolution of animal colour vision and visual communication signals. Vis. Res., v.48, p.20422051, 2008.

RODRIGUES, F.H.G. História natural $e$ biologia comportamental do veado campeiro (Ozotocerus bezoarticus) em cerrado do Brasil Central. 1996. Tese (Doutorado) - Universidade de Campinas, Campinas, SP.

SCHMITZ, L.; MONTANI, R. Morphological differences between the eyeballs of nocturnal and diurnal amniotes revisited from optical perspectives of visual environments. Vis. Res., v.50, p.936-946, 2010.

SUSSADEE, M.; PHAVAPHUTANON, J.; KORNKAEWRAT, K. et al. Normal clinical electroretinography in poodle, labrador retriever, Thai ridgeback and Thai bangkew dogs. J. Vet. Sci., v.16, p.67-74, 2015.

SUSSADEE, M.; VORAWATTANATHAM, N.; PINYOPUMMIN, A. et al. Scotopic eletroretinography in fishing cat (Prionailurus viverrinua) and Leopard cat (Prionailurus bengalensis). Vet. Ophthal., v.1, p.1-5, 2016.

TOMAS, W.M.; BECCACECI, M.D.; PINDER, L. Cervo-do-Pantanal (Blastocerus dichotomus). In: DUARTE, J.M.B. Biologia e conservação de cervídeos sul-americanos: Blastocerus, Ozotocerus e Mazama. Jaboticabal: Funep, 1997. p.24-40.

VERCAUTEREN, K.C.; PIPAS, M.J. A review of color vision in White-tailed deer. Wild. Soc. Bull., v.31, p.684-691, 2003.

VOGLIOTII, A. História natural de Mazama bororo (Artiodactyla; Cervidae) através de etnozoologia, monitoramento fotográfico $e$ rádio-telemetria. 2003. 99f. Dissertação Mestrado em Ecologia de Agroecossistema) Escola Superior de Agricultura "Luiz de Queiroz", Universidade de São Paulo, Piracicaba, SP. 